\title{
Effectiveness of the GAEC standard of cross compliance Management of set aside on soil erosion control
}

\author{
Paolo Bazzoffi \\ CRA-ABP Agricultural Research Council, Agrobiology and Pedology Research Centre, Firenze, Italy
}

\begin{abstract}
The GAEC standard Management of set aside is applied to arable lands subjected to set aside and kept non-cultivated throughout the year. The standard is also applied to other set aside areas eligible for direct payments. For the implementation of this Standard, the farmer must assure the presence of natural or artificial green cover on the surface throughout the year and adopt consistent agronomic practices as mowing, or other equivalent, in order to maintain the normal state of soil fertility, protect wildlife, prevent the formation of a potential inoculum of fires, especially during drought and prevent the spread of weeds. Up to the CAP Health Check the legislation on the set aside required the farmer to plough the soil by mid-May. Therefore, the natural vegetation cover could neither establish nor express its value against erosion throughout the year. Since mid 2004, cross compliance has banned ploughing of set aside surfaces. This novelty is very important in relation to the effectiveness of the standard in erosion control. In Italy there are only few studies carried out in the field that have measured the effect of set aside on soil erosion. The few existing experiments regarded the effect of set aside managed in accordance with the CAP dictates prior to the CAP Health Check. The results of case studies show very contrasting results regarding soil erosion on set aside plots managed through the annual ploughing in the period in which this rule remained in force. This finding can be explained by considering that most of soil erosion in the Mediterranean environment is determined by extreme events; so, set aside resulted ineffective in protecting the soil, when very erosive events occurred on bare
\end{abstract}

Correspondence: Paolo Bazzoffi, CRA-ABP Agricultural Research Council, Agrobiology and Pedology Research Centre, p.za M. D’Azeglio 30, 50121 Firenze, Italy.

Tel. +39.055 .2491228 - Fax: +39.055 .241485 .

E-mail: paolo.bazzoffi@entecra.it

Key words: cross compliance, GAEC Standards, set aside, soil erosion.

Acknowledgements: we greatly acknowledge Massimo Aglietti, of the CRAABP staff, for the peer review of the text in English.

Received for publication: 24 March 2011.

Accepted for publication: 28 April 2011.

(C) Copyright P. Bazzoffi, 2011

Under no circumstances figures can be used without prior written consent of the copyright owner.

Licensee PAGEPress, Italy

Italian Journal of Agronomy 2011; 6(s1):e5

doi:10.4081/ija.2011.6.s1.e5

This work is licensed under a Creative Commons Attribution NonCommercial 3.0 License (CC BY-NC 3.0). soil (soil in seed bed condition after ploughing and harrowing) when the plant cover of soil was still scarce. In these conditions soil erosion rate resulted similar to that observed in the intensive cropping systems. On the contrary, for events occurred when the natural vegetation was sufficiently developed, the beneficial effect of set aside in limiting erosion was similar to that exerted by total grass cover. In general, it can be argued that on plough set aside, an average period of 2 months is needed for the establishment of natural cover sufficient enough to ensure a significant protection of soil from erosion. The results show that in Italy set aside before the CAP Health Check might have determined a decrease of soil erosion by $50 \%$ (on average). Since 2005 , set aside under cross compliance regime appears to have had a greater beneficial effect than before in reducing erosion, as total grass cover was able to decrease soil loss by $98 \%$ compared to intensive farming systems.

\section{Introduction}

\section{Legislation and goal of the study}

GAECs (Standards of Good Agricultural and Environmental Condition) form part of the requirements under cross compliance and apply to anyone who receives payments under Single Payment Scheme. GAECs set requirements for farmers in respect of soils, as well as maintaining a range of habitat and landscape features that are characteristic of the Italian countryside. The GAEC standard Management of set aside is applied to arable lands subjected to set aside $^{1}$ and kept non-cultivated throughout the year. The standard is also applied to other set aside areas eligible for direct payments. This GAEC Standard had been introduced under rule 4.2 by the following Mipaaf $^{2}$ decrees on Cross compliance since mid 2004 (Decree $1787 / 2004$ et seq.) up to end of 2009 , with the aim of ensuring a minimum level of habitat maintenance. Then, the following Decree 30125 of December 2009 (after the Health Check) maintained this Standard (renamed standard 1.2 minimum soil cover) under the Rule 1 (soil protection measures) with the aim of ensuring the protection of soil from erosion. To apply the implementation of this standard, the farmer must comply with the following requirements: i) assuring the presence of green cover, natural or artificial, throughout the year; ii) implementing of agronomic practices consisting of mowing, or other equivalent, in order:

1) to maintain the normal state of soil fertility;

2) to protect wildlife,

3) to prevent the formation of a potential inoculum of fires, especially during drought and;

4) to prevent the spread of weeds.

${ }^{1}$ Set-aside was introduced in the Common Agricultural Policy (CAP) by the EEC regulation $1094 / 88$.

${ }^{2}$ Mipaaf (Ministry of Agricultural, Food and Forestry Policies). 
The goal of this study was to verify the effectiveness of set aside established under the two contrasting PAC regimes (before and after the introduction of cross compliance in the rural development policies) by extrapolating the soil erosion values observed on case studies to the Italian set aside area from 1992 to 2009. Data of case studies come partly from literature and partly from specific experiment set up within the EFFICOND ${ }^{3}$ project.

To evaluate the effectiveness of the GAEC standard Management of set aside in relation to erosion, it is important to consider that soil erosion tolerance $(\mathrm{T})$ cannot be fixed in relation to a precise threshold value $\left(\mathrm{Mg} \cdot \mathrm{ha}^{-1} \cdot \mathrm{yr}^{-1}\right)$ only, assumed valid for all soils and situations. The acceptable limit should be set in consideration of the hazard, vulnerability and value that is threatened by erosion, taking into account, therefore, the different nature and fragility of the soil, the economic value of the land and the off-site effects of erosion (Bazzoffi, 2009).

Despite the complexity of these issues, the rural development policies need a drastic simplification of the criteria to know whether the GAEC standard Management of set aside is effective or not and, consequently, to decide whether it is necessary to modify the standard or the typology of land eligible for the allocation of monetary resources. The best compromise can be found by adopting the limit of $11.2 \mathrm{Mg} \cdot \mathrm{ha}^{-1}$. $\mathrm{yr}^{-1}$. This value, which was defined in the United States by the Natural Resources Conservation Service (NRCS), is largely adopted all over the world in territorial risk analysis.

\section{Effect of vegetative cover on soil erosion}

On sloping land, when the soil is bare or scarcely covered by vegetation or plant residues, soil erosion exerts its maximum effect, due to the direct rain splash on the soil surface. If raindrops have sufficient kinetic energy they can detach and move soil particles and destroy soil aggregates.

Residues of plants and vegetation canopy protect the soil from erosion by intercepting falling raindrops and by slowing down the movement of surface runoff, meanwhile allowing excess surface water to infiltrate. Setting aside arable lands determines the establishment of a natural vegetation cover that exerts a protective action on soil. Thus, the evaluation of the effectiveness of the GAEC standard in reducing soil erosion can be done through the quantification of the beneficial effect of vegetative cover. This beneficial effect mainly depends on the percentage of ground cover and also on the quantity and architecture of the aerial part of plants and residues. Even plant residues partially embedded in the soil and root residues are important in controlling erosion because they provide channels that allow water to move into the soil.

Figure 1 shows two graphs, taken from Wischmeier and Smith (1978) on the combined mulch and canopy effects on Soil-loss Ratio when the average fall distance of drops from canopy to the ground is about $0.5 \mathrm{~m}$ (upper pannel) e $1 \mathrm{~m}$ (lower pannel). The Soil-Loss Ratio is the ratio of soil eroded from land under a specific crop and management system to the corresponding soil loss from clean-tilled continuous fallow. The Soil-Loss Ratio is equal to the $\mathrm{C}$ factor of the Universal Soil Loss Equation USLE (1) (Wischmeier and Smith, 1978). This is a simple empirical model validated through many direct observations in the field.

\footnotetext{
${ }^{3}$ EFFICOND (EFF = Effectiveness of environmental standards, COND $=$ Cross compliance) is a CRA (Agricultural Research Council) project started in 2009 to meet the specific need of NRN (National Rural Network) to monitor and evaluate the effectiveness of environmental protection actions mandated by the CAP to national agricultural policy and implemented by the Regional Rural Development Plans (RDP). The main project objectives are the evaluation of GAEC standards implemented under cross compliance and the development of agrienvironmental indicators for nation-wide scenario analysis. The EFFICOND project involves
}

10 operational units with experimental fields located throughout the country.

Although the equation has many limitations, it is widely used for its ease of application and its robustness (Desmet and Govers, 1996), especially in its revised version of RUSLE (Renard et al., 1997).

The USLE model estimates soil erosion by means of the following empirical equation:

$$
\mathrm{A}=\mathrm{R} \cdot \mathrm{K} \cdot \mathrm{L} \cdot \mathrm{S} . \mathrm{C} . \mathrm{P}
$$

where:

$\mathrm{A}=$ soil erosion risk $\left(\mathrm{Mg} \cdot \mathrm{ha}^{-1} \cdot \mathrm{yr}^{-1}\right)$

$\mathrm{R}=$ Rainfall Erosivity Factor $\left(\mathrm{MJ} \cdot \mathrm{mm} \cdot \mathrm{ha}^{-1} \cdot \mathrm{h}^{-1} \cdot \mathrm{yr}^{-1}\right)$

$\mathrm{K}=$ Soil Erodibility Factor $\left(\mathrm{Mg} \cdot \mathrm{ha} \cdot \mathrm{h} \cdot \mathrm{ha}^{-1} \cdot \mathrm{MJ}^{-1} \cdot \mathrm{mm}^{-1}\right)$

$\mathrm{L}=$ Length Factor (dimensionless)

$\mathrm{S}=$ Slope Factor (dimensionless)

$\mathrm{C}=$ Cover Management Factor (dimensionless)

$\mathrm{P}=$ Practices aimed at erosion control (dimensionless)

The main effect of set aside is the development of natural herba-
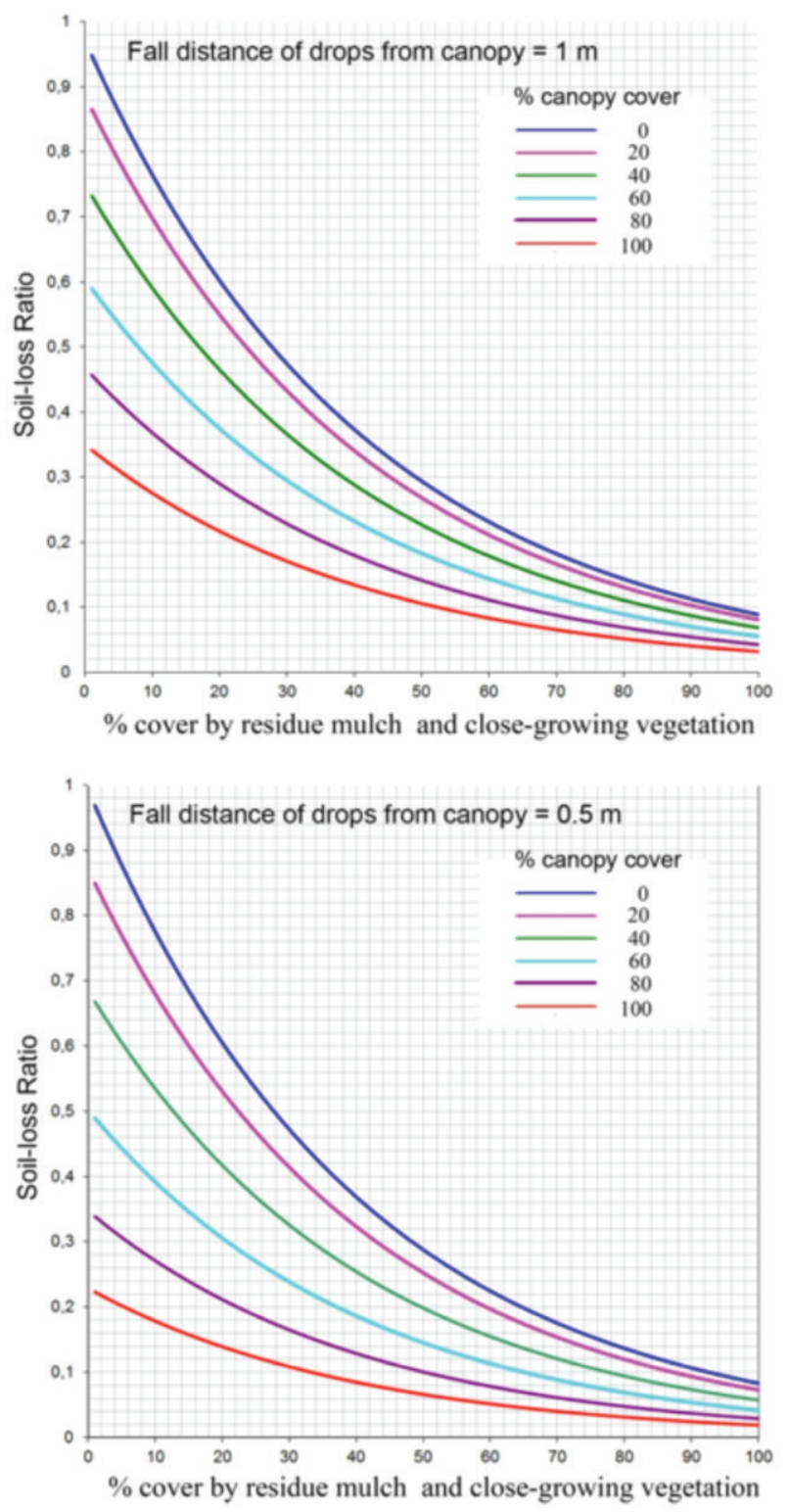

Figure 1. Combined mulch and canopy effects on Soil-loss Ratio when the average fall distance of drops from canopy to the ground is about $0.5 \mathrm{~m}$ (upper ) e $1 \mathrm{~m}$ (lower). From Wischmeier and Smith (1978). 
ceous vegetation. Therefore, the protective effect on soil erosion mainly depends on the percent of land cover on set aside land. The following equation (2), derived from data of Figure 1, can be used to evaluate the $\mathrm{C}$ factor for set aside in relation to the combined effect of mulch and canopy cover:

$$
\mathrm{SRL}_{0.5 \mathrm{~m}}=\mathrm{e}^{\left(-0.00378-0.02481 \mathrm{x}-0.00146 \mathrm{y}^{1.5}\right)}
$$

where:

$\mathrm{SLR}_{0.5 \mathrm{~m}}=$ Soil loss ratio, for a fall distance of drops from canopy to the ground of about $0.5 \mathrm{~m}$ (which can be considered appropriate for herbaceous vegetation).

$\mathrm{x}=\%$ of soil surface covered by residue mulches and stems from closegrowing vegetation.

$y=\%$ of soil surface covered by canopy (leaves and branches that do not directly contact the soil).

In order to display the effectiveness of the different percentages of soil cover, Table 1 shows an example of six erosion values for bare soil (seed-bed condition) and the calculated percentage of soil cover (by residue mulch and close-growing vegetation) needed to decrease soil erosion within the tolerance limit of $11.2 \mathrm{Mg} \cdot \mathrm{ha}^{-1} \cdot \mathrm{yr}^{-1}$. The analysis was done by using the equation (2) and by assuming $0 \%$ canopy cover.

\section{Field experiments}

In Italy there are only few studies carried out in the field who have measured the effect on erosion and runoff of set aside managed in accordance with the dictates of cross compliance (Norm 4.2 or standard 1.2 (Decree 247/2009). Up to the introduction of cross compliance, two forms of set aside were in force: the mandatory and voluntary set aside. The only main difference between these two forms, with regard to erosion control, was related to the extension of the dedicated areas. Soil ploughing by mid-May was requested for both forms of set aside: the five-year rotational set aside and the multiyear set aside. The obligation to plough made the two forms of set aside quite similar under the aspect of soil erosion control. In fact, the natural vegetative cover was not given to the opportunity to fully establish and express its anti-erosive value throughout the year for none of them. The cross-compliance regime introduced the prohibition of carrying out the ordinary farming practices that had been allowed on set aside land for years. Especially, ploughing is only granted exceptionally. This new element is very important in relation to the effectiveness of set aside against erosion, as shown by the graphs of Figure 1 and Table 1. In Italy some field trials on set aside were conducted at plot, hill slope or micro-catchment scale by comparing different land uses, all of them managed with the annual ploughing of soil by mid-May, as requested by the CAP rules in force before 2005. Among the different set aside systems, only the pasture use can be considered similar to the management of land allowed by cross-compliance, as pasture is permitted by cross-compliance (before and after the Health Check) and assures a complete vegetation cover throughout the year.

\section{Case study \#1}

In order to assess the effectiveness of vegetation cover throughout the year in reducing runoff and soil erosion an experiment was conducted in the two agricultural years ${ }^{4}$ 1995-1997 at the experimental farm of the CRA-ABP located at Vicarello (Volterra, Italy) (Figure 2).

In this area, on Vertisols textured clay loam (Pliocene origin), are present, since the 60 's, 8 hydraulically isolated plots, equipped to collect runoff from a whole hill side. The plots, $75 \mathrm{~m}$ long on the maximum slope and $15 \mathrm{~m}$ wide, with $25 \%$ gradient, have been equipped with hydrological units for sampling sediment and for the extremely detailed electronic recording of runoff events (Bazzoffi, 1993a,b).

${ }^{4}$ Agricultural year $=$ period between the primary tillage at the beginning of the crop cycle (g.e. july) to harvest time in the following year, not necessarily corresponding to 12 months.
The theses ( 2 replicates for a total of 8 plots) were as follows: i) set aside covered by Atriplex Halimus L. shrubs (mid-sized, bushy, evergreen shrub, Figure 3) and natural grass vegetation, sheep-grazed with a load of $1 \mathrm{LU} / \mathrm{ha}$; ii) alfalfa; iii) wheat; iv) bare soil maintained in seed-bed condition (ploughed and disked, then kept free of weeds through chemical weed control). The latter thesis reflects the condition of the soil after mid-May tilling in the set aside. The statistical analysis (Bazzoffi et al., 1997) showed a highly significant decrease of soil erosion and runoff due to vegetation cover throughout the year. The average erosion per event passed from $0.42 \mathrm{Mg} \mathrm{ha}^{-1}$ in the case of bare soil to $0.0033 \mathrm{Mg} \mathrm{ha}^{-1}$ in treatments with vegetation cover throughout the year, representing a reduction of about 127 times (-99.2\%) (Table 1 and

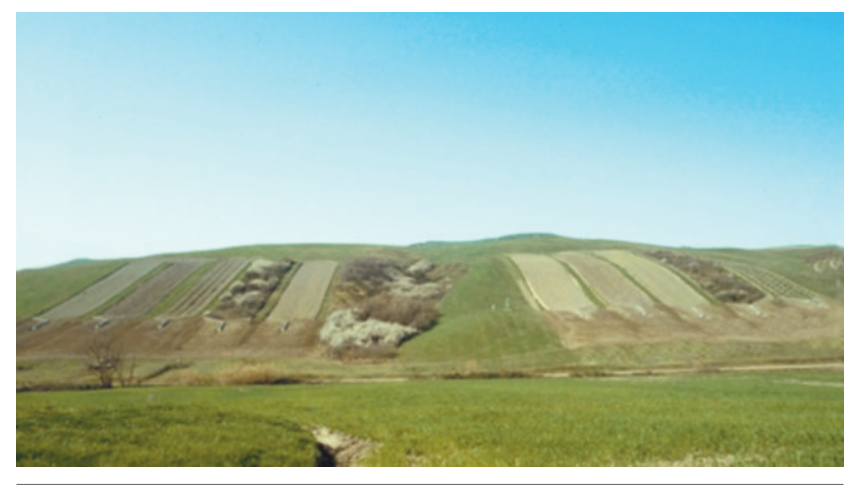

Figure 2. Experimental plots (Vicarello experimental farm, Volterra, Italy).

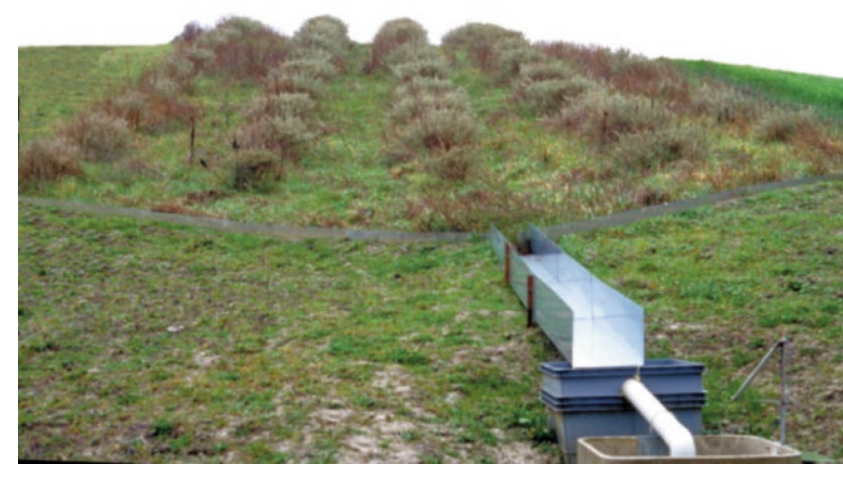

Figure 3. Close view of the set-aside plot with permantent soil cover (natural vegetation and grazing shrubs, Atriplex halimus $\mathrm{L}$. Sp.).

Table 1. Percentage of soil cover needed in order to decrease soil erosion values to the tolerance threshold $\left(11.2 \mathrm{Mg} \cdot \mathrm{ha}^{-1} \cdot \mathrm{yr}^{-1}\right)$, in six examples.

$\begin{array}{cc}\begin{array}{c}\text { Soil erosion } \\ \text { (bare soil ) }\end{array} & \begin{array}{c}\text { Percentage of soll } \\ \text { cover needed }\end{array} \\ \mathrm{Mg}^{-1} \cdot \mathrm{hr}^{-1} \cdot \mathrm{yr}^{-1} & \end{array}$

\begin{tabular}{|ll}
15 & 12.2 \\
20 & 23.1 \\
\hline 30 & 40.4 \\
50 & 60.8 \\
\hline 100 & 87.9 \\
120 & 94.4 \\
\hline
\end{tabular}


Figure 4). The average runoff per event passed from $41.81 \mathrm{~m}^{3} \mathrm{ha}^{-1}$ in the case of bare soil to $3.68 \mathrm{~m}^{3} \mathrm{ha}^{-1}$ in treatments with set aside (vegetation cover throughout the year).

Also in comparison with wheat and alfalfa the set aside treatment showed a significant effectiveness to reduce erosion and runoff. In fact, the mean soil erosion per event observed for winter-wheat plots was $0.067 \mathrm{Mg} \mathrm{ha}^{-1}$ and for alfalfa was $0.042 \mathrm{Mg} \mathrm{ha}^{-1}$, which is respectively 20 times and 13 times greater than the set aside. The same behavior was observed with regard to mean runoff volume per event. Runoff volume for winter wheat and alfalfa treatments was equal respectively to 15.86 and $23.36 \mathrm{~m}^{3} \mathrm{ha}^{-1}$, both values were significantly higher than in set aside $\left(3.68 \mathrm{~m}^{3} \mathrm{ha}^{-1}\right)$.

These data confirm the previous observations by Zanchi (1990) who carried out a multi-year experiment at the same Vicarello experimental station, on plots $110 \mathrm{~m}$ long and $15 \mathrm{~m}$ wide on a hill slope with $25 \%$ gradient. Zanchi's results showed an average value of $4.42 \mathrm{Mg} \mathrm{ha}^{-1}$ of soil erosion from winter-wheat plots and $0.13 \mathrm{Mg} \mathrm{ha}^{-1}$ from permanent meadow plots. Mean soil erosion on set aside plots resulted of $0.12 \mathrm{Mg}$ $\mathrm{ha}^{-1}$ (-97.3\% compared to winter wheat). All differences resulted statistically significant. Similarly, cumulative runoff during the period of the tests has increased from $3179.0 \mathrm{~m}^{3} \mathrm{ha}^{-1}$ observed in winter wheat to $1524 \mathrm{~m}^{3} \mathrm{ha}^{-1}$ observed in meadow $1361.5 \mathrm{~m}^{3} \mathrm{ha}^{-1}$ ( set aside). These results show that set aside without tillage ( as required by cross compliance), has the same protective value of meadow, reducing soil erosion and runoff by $97.3 \%$ and $57.1 \%$ respectively.

Soil grassing maintained throughout the year was also extremely effective in decreasing the removal of soluble salts. In fact, in winter wheat plots, in the experimental period, the removal of salts was equal to $95 \mathrm{~kg} \mathrm{ha}^{-1}$ while in the plots covered by herbaceous vegetation was $3 \mathrm{~kg} \mathrm{ha}^{-1}$, that is 32 times lower. This is of particular interest in relation to pollution of surface water delivered from the farm to the river network as well as pollution of subsurface water.

\section{Case study \#2}

At the experimental farm of CRA-RPS (Tor Mancina, Monterondo, Roma, Italy) in the period 1991-1994 a research was carried out on the influence of four different types of turf: i) natural grass; ii) sowed grass (graminaceous mix); iii) sowed grass (mix with a predominance of leguminous species); iv) natural grass under forest and v) non-rotational set aside with mechanical weeding.

Plots were hydrological units equipped with instrumentation to collect runoff and for the measurement of rainfall, described by Raglione et al. (1997) (Figure 5).

For the purposes of this study is important to highlight the comparison between the non-rotational set aside versus the natural grass cover. The statistical comparisons showed that soil erosion and runoff were significantly higher in set aside treated with ploughing than natural grass cover. In fact, the average erosion by event was $235.7 \mathrm{~kg} \mathrm{ha}^{-1}$ in ploughed set aside and $3.69 \mathrm{~kg} \mathrm{ha}^{-1}$ in natural grass cover. That is, natural grass cover reduced erosion by $98 \%$ respect to ploughed set aside. Seemingly, the other treatments with different types of grass cover significantly reduced soil erosion.

The same effect was observed with respect to the average volume of runoff by event. On set aside the mean runoff was equal to $15.3 \mathrm{~m}^{3} \mathrm{ha}^{-1}$ compared with $6.3 \mathrm{~m}^{3} \mathrm{ha}^{-1}$ of the treatment with vegetation cover throughout the year. Also for treatments with different types of grass cover the mean runoff volumes were significantly lower than for setaside treatment.

\section{Case study \#3}

In the experimental farm of the CRA-ABP at Fagna (Scarperia, Firenze, Italy) an experiment was conducted on the effect of different types of land uses on erosion, among which set aside. The experiment lasted for nine years and was conducted on plots sized $20 \mathrm{~m}$ long and 5 meters wide with a gradient of $14 \%$. Soil is classified as Vertic Eutrochrept (Soil Survey Staff, 1975) with clay texture subject to crack in summer.

The experimental results (Zanchi, 1990) show that polyphite grass cover significantly decreased soil erosion compared to other soil uses. In fact, while in grassed plots the mean erosion was $2.2 \mathrm{Mg} \mathrm{ha}^{-1}$ yearin winter wheat and in corn plots soil erosion was equal to 5.6 and 18.8 $\mathrm{Mg} \mathrm{ha}^{-1}$ year ${ }^{-1}$ respectively. The difference resulted highly significant. Permanent grass cover also decreased the volume of runoff compared to other uses (Figure 6).

\section{Case study \#4}

In the experimental farm of Ancona University at Agugliano Ancona (Ancona, Italy), between 1994 and 1995, trials were carried out on clayloam plots (12\% sand, $43 \%$ silt and $45 \%$ clay) with $20 \%$ slope. The experiment consisted in the comparison of non-rotational set-aside versus an ordinary crop system (winterwheat followed by sunflower) with two levels of agro-chemical inputs.

The results of these tests (Rivoire et al., 1997) clearly bring out the inadequacy of set aside in controlling runoff when the soil has just been
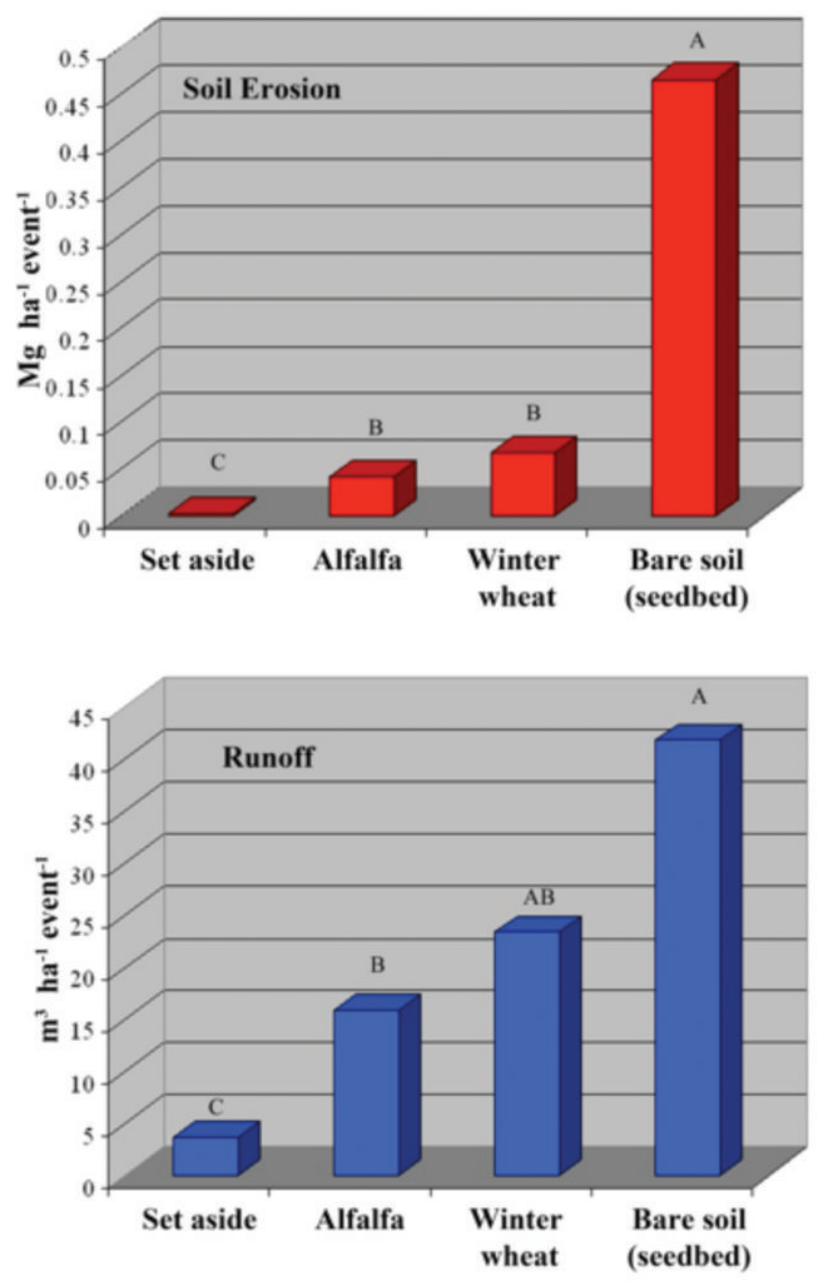

Figure 4. Mean erosion and runoff by event. Comparison between set aside maintained grassed throughout the year and other soil uses (Vicarello, Volterra, Italy), on plots with $25 \%$ gradient. Observations from 1995 to 1997 . Means with different letters differ significantly $(\mathrm{P} \leq \mathbf{0 . 0 0 5})$. 
tilled (Figure 7). By taking into account, for the purposes of this study, only the comparison between the high agro-chemical input (intensive agriculture) treatment versus set aside, it was observed that rain events occurred between $9^{\text {th }}$ and $13^{\text {th }}$ April 1994 led to an erosion of $2.8 \mathrm{Mg} \mathrm{ha}^{-1}$ in the set aside, as against $0.03 \mathrm{Mg} \mathrm{ha}^{-1}$ in high-input treatment. On the contrary, when the set-aside grass cover was well developed, there was a greater effectiveness in controlling runoff and erosion. In fact, during the rainfall events that occurred between $14^{\text {th }}$ and $16^{\text {th }}$ June 1995 , the erosion observed in the high-input plots was equal to $4.43 \mathrm{Mg} \mathrm{ha}^{-1}$, while in the set side was equal to $0.024 \mathrm{Mg} \mathrm{ha}^{-1}$ (a decrease of 99.5\%).

\section{Case study \#5}

Since 1993, the Department of Agronomy and Plant Genetics of the University of Naples (Postiglione et al., 1997) has conducted experiments in a hilly environment of Irpinia $(700 \mathrm{~m})$ at S. Angelo dei Lombardi (in the Province of Avellino) on different types of soil tillage, rotations and contrasting orientation of crops on the hill slope (row
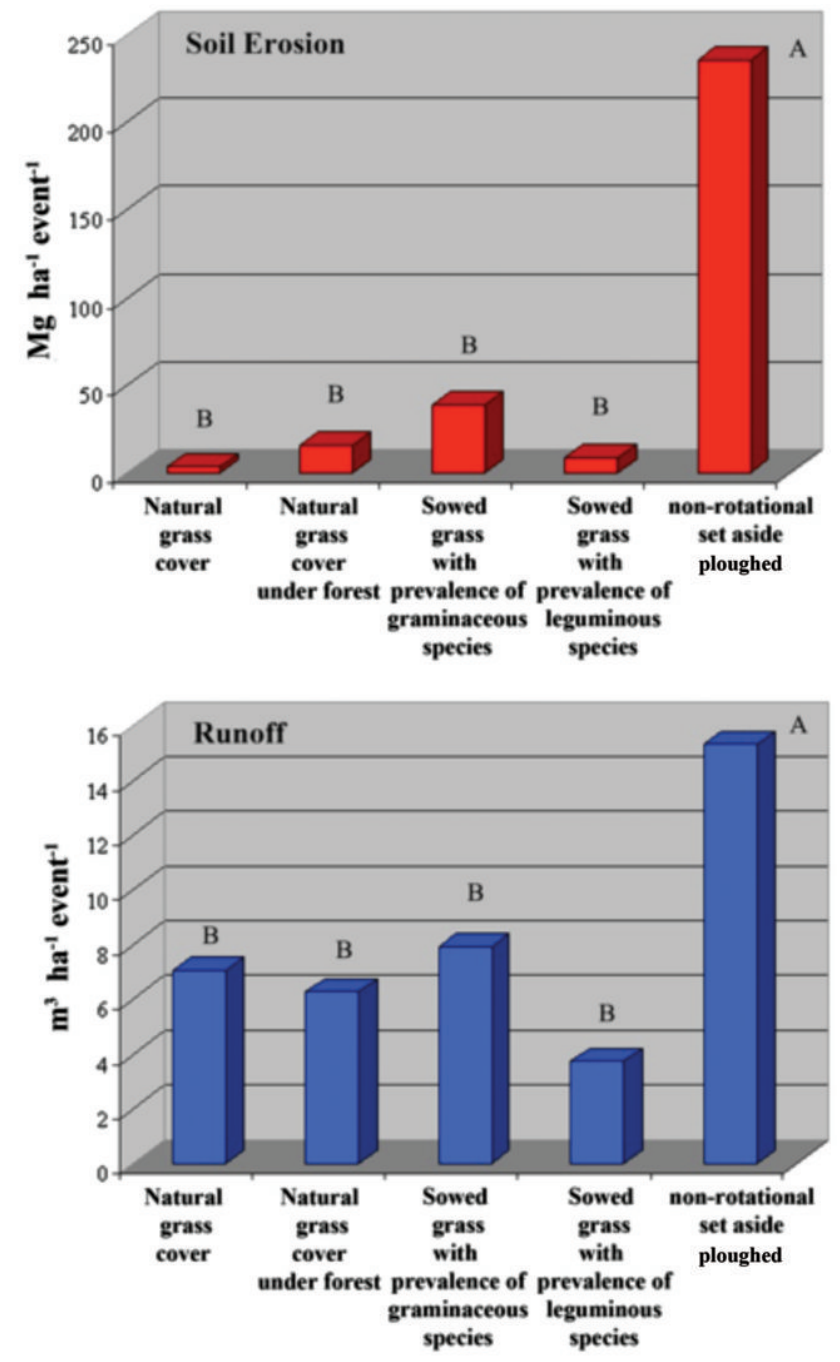

Figure 5. Mean erosion and runoff by event. Comparison between set aside maintained grassed throughout the year and other soil uses among which the non-rotation set aside with mechanical weeding (Tormancina, Monterotondo, Roma, Italy). Reprocessed from Raglione et al. (1997) data. Means with different letters differ significantly $(P \leq 0.005)$. crops planted along and across the maximum hill slope gradient) (Figure 8).

For the purposes of this study it is interesting to note the comparison between the rotational set aside, the mixed alfalfa + fescue grass cover and winter wheat. The data (means of two crop cycles), show that winter wheat decreases erosion by $46 \%$ compared to set aside. A similar behavior is observed for grass cover, which reduces erosion by $43 \%$ compared to set aside. Winter wheat and grass cover reduced runoff by $23 \%$ and $22 \%$, respectively when compared to set aside. From these findings it can be said that the rotational set-aside exposed the soil to higher erosion risk during the periods when the soil was bare (after tillage) when compared to winter wheat treatment.

\section{Case study \#6}

A long-term research on soil erosion and runoff was carried out by the University of Bologna, Department of Science and Agri-environmental Technology, in the Centonara small catchment (197 ha), near Bologna, situated at an altitude between 84 and $350 \mathrm{~m}$ above sea level
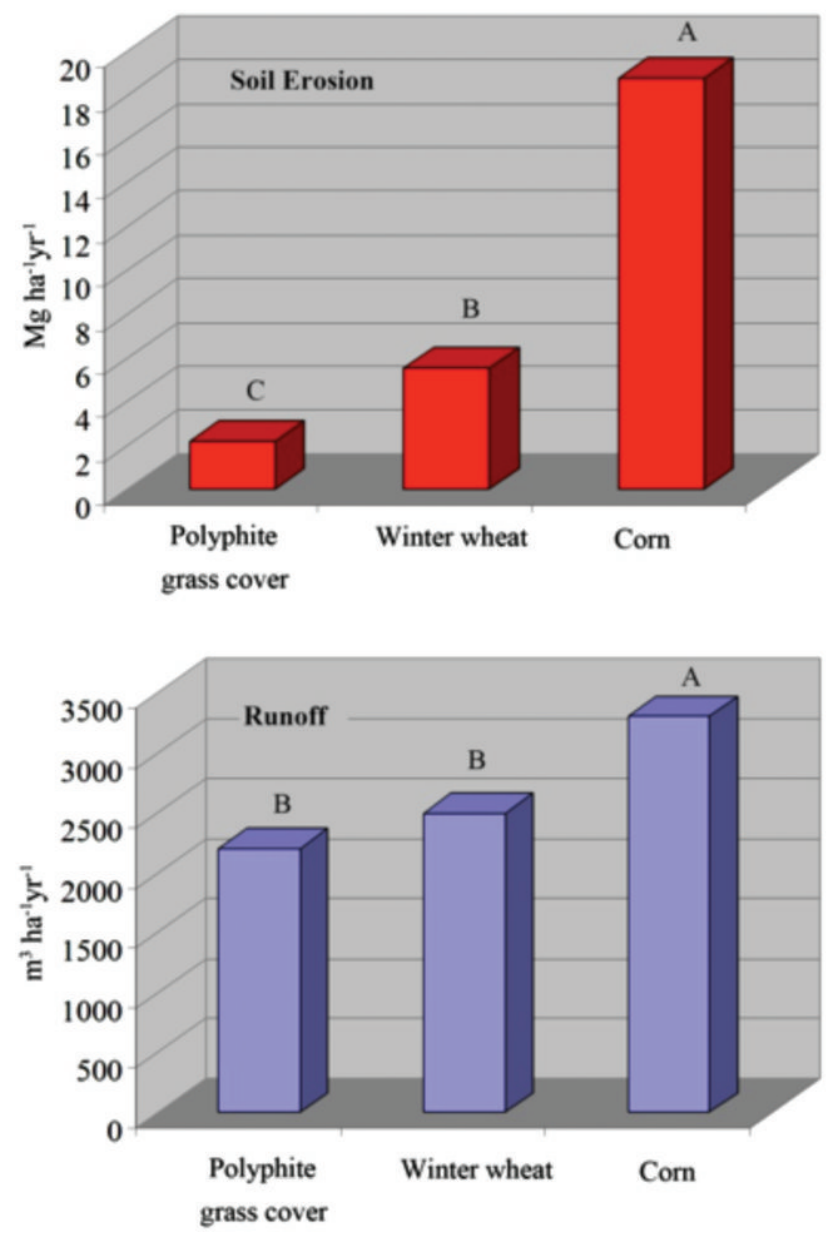

Figure 6. Mean erosion and runoff per year. Comparison between set aside maintained grassed throughout the year and other soil uses (Fagna, Scarperia - Mugello, Firenze, Italy). Reprocessed from Zanchi (1990) data. Means with different letters differ significantly $(\mathbf{P} \leq \mathbf{0 . 0 0 5})$. 
with an average gradient of $28.2 \%$ and average slope of the cultivated area (which covers $45 \%$ of total) of $15.2 \%$ (Ventura et al. 2004).

The monitoring of runoff and erosion lasted six years, from 1994 to 2000, during which the hydrological parameters were put in relation to land use, as shown in Table 2 . The analysis performed by the authors on the impact of land use on erosion showed that the total quantity of sediment transported by stream water, measured at the basin outlet, is heavily dependent on the percentage of agricultural land dedicated to set aside plus the percentage of non-agricultural land covered by natural vegetation. The equation that links the net production of sediment from the Centonara basin (soil erosion minus re-sedimentation within the basin) to percent of the basin area covered by set-aside + natural vegetation is as follows:

$$
\mathrm{y}=46.65 \mathrm{e}^{0.07 \mathrm{x}}
$$

where

$\mathrm{y}=\mathrm{Mg} \mathrm{ha}^{-1} \mathrm{yr}^{-1}$

$\mathrm{X}=$ percentage of the basin area covered by set-aside + natural vegetation. The equation has a coefficient of determination $R^{2}=0.72$ that, in hydrology, is considered very high.

From Figure 9, which shows graphically the equation, it can be seen as a low vegetation cover (eg: $20 \%$ of the area) is able to contain the erosion within the tolerance limit of $11.2 \mathrm{Mg}$ per year (limit USDA). Ultimately, this trial also highlights the remarkable effectiveness of the multi-year set aside in protecting soil from erosion.
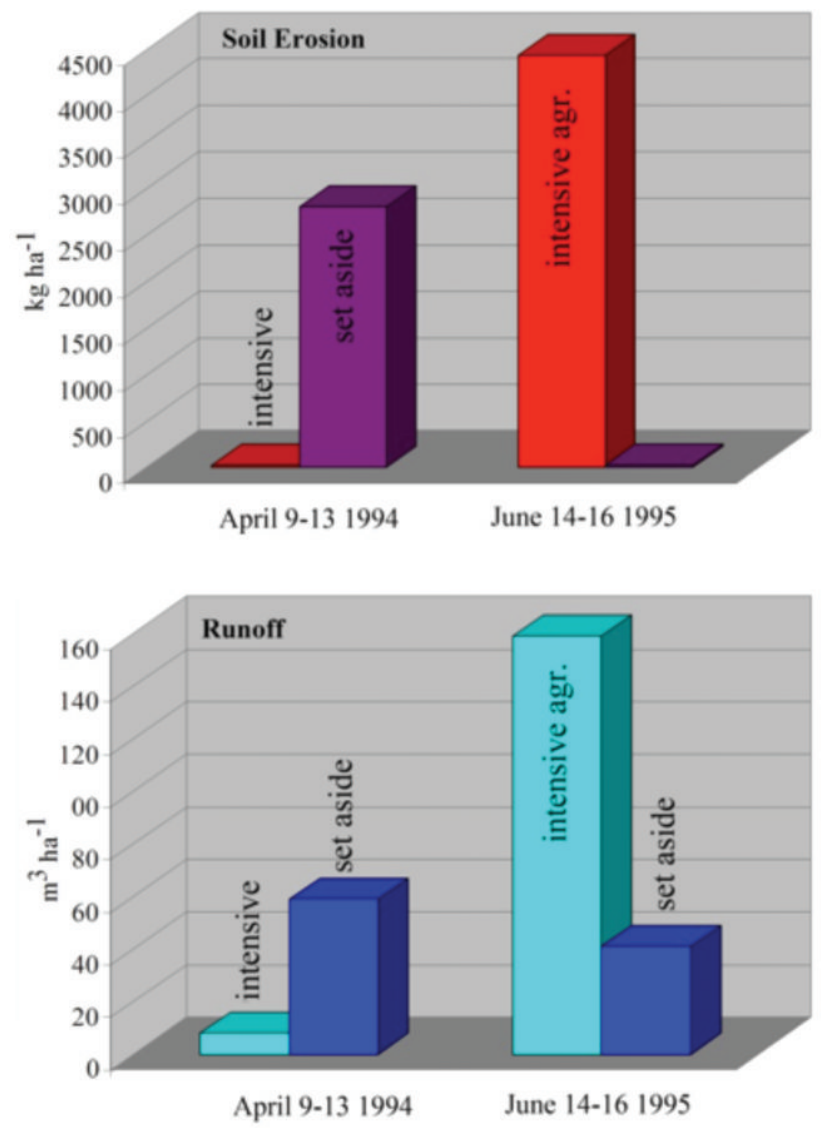

Figure 7. Comparison of soil erosion and runoff between rotational set aside and high agro-chemical input (intensive agriculture) treatment (Agugliano, Ancona, Italy). Reprocessed from Rivoira et al., (1997) data.
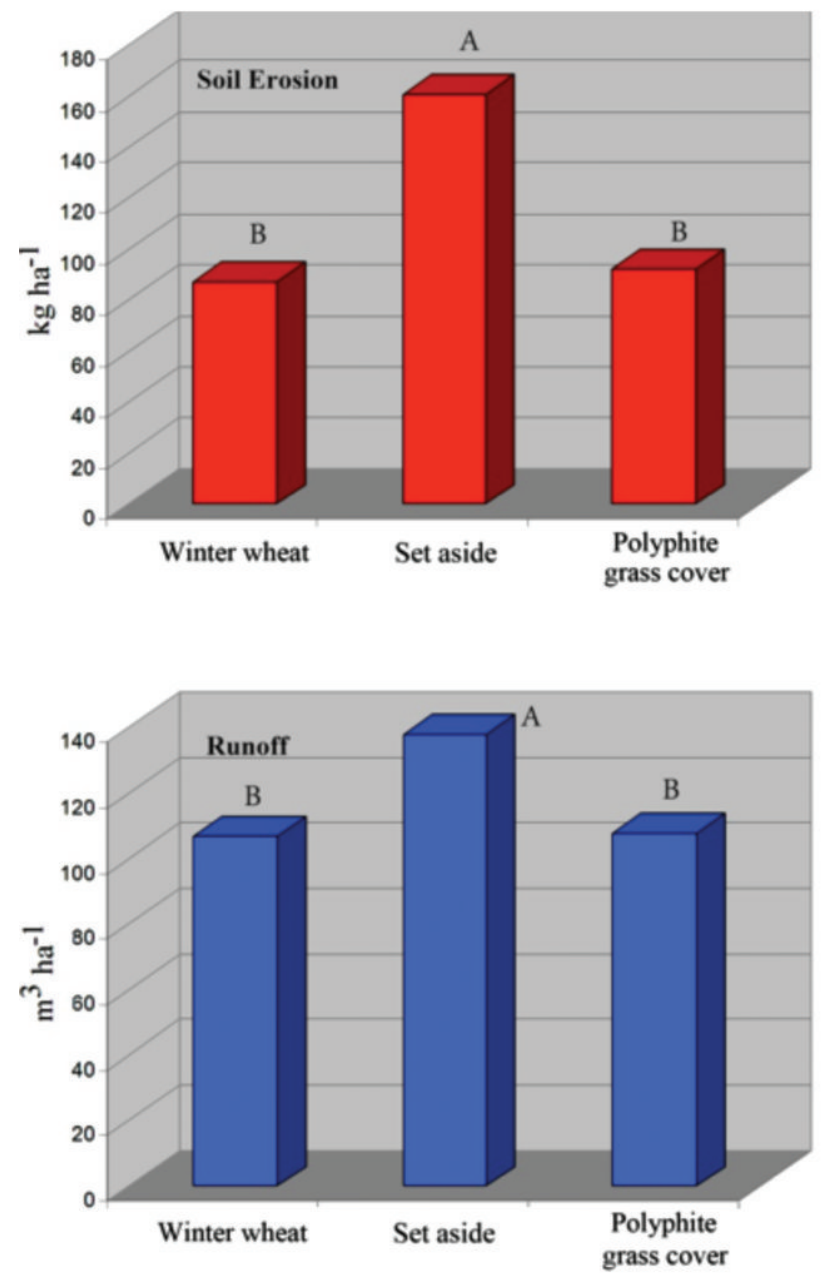

Figure 8. Comparison of soil erosion and runoff between rotational set aside, winter wheat and polyphite grass cover. Reprocessed from Postiglione et al., (1997) data. Set aside differs significantly from other soil uses $(P \leq 0.005)$.

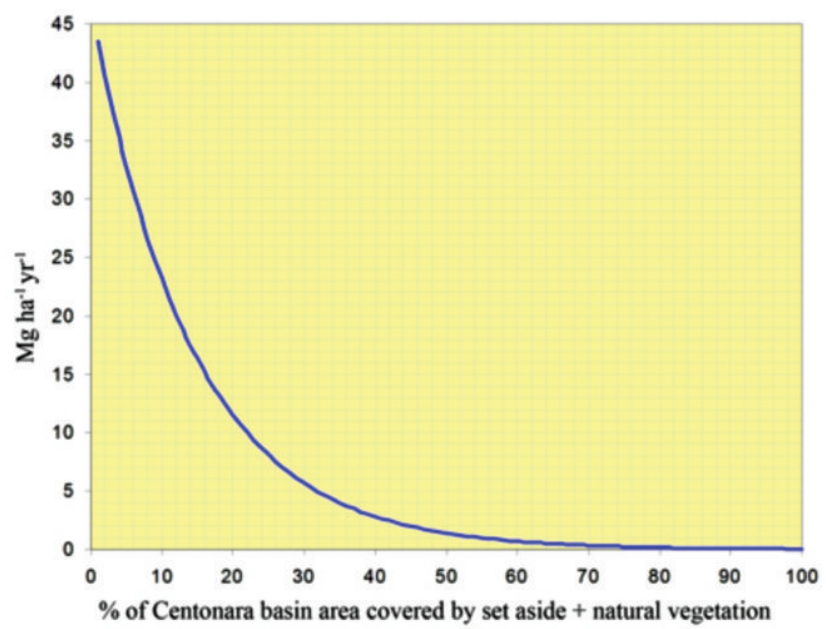

Figure 9. Centonara Basin. Effect of set-aside + grassland vegetation in reducing soil erosion (graphical representation of equation (3) (derived from Ventura et al., 2004 data). 


\section{Evaluation of the effect of set aside on soil erosion in Italy}

The results reported in the case studies very clearly show that it is impossible to quantify the effect exerted by set aside in controlling soil erosion when it was managed through the annual soil ploughing before mid-May, as made mandatory by EEC regulation 1094/88 before the enforcement of cross compliance. To explain the very contrasting results observed in field trials, it must be considered that in the Mediterranean environment most erosion is caused by critical rainfall events; so that, soil erosion was noticeable for extreme events occurred when soil was just tilled or did not have enough vegetative cover. Consequently, in bare soil conditions, soil erosion for set aside was high and similar to that observed in intensive cropping systems. On the contrary, erosion was very low when erosive rainfall occurred with the soil surface sufficiently covered by natural vegetation.

To judge the effectiveness, at national scale, of the uncultivated set aside (adopted before the enforcement of cross compliance) it must be considered that the results of trials (especially case study 3 and 4) showed a decrease in soil erosion of approximately $50 \%$ in set aside respect to bare soil. Case studies 1, 2 and 3 show that total grass cover with the exclusion of ploughing reduces the removal of soil by $98 \%$ compared to intensive farming systems and remained below $3 \mathrm{Mg} \mathrm{ha}^{-1}$ year $^{-1}$. Thus, it can be argued that since 2005 (being the first year of real application of cross compliance by farmers), erosion on set aside under cross compliance might have reduced soil erosion by approximately $98 \%$ respect to intensive agriculture and below $3 \mathrm{Mg} \mathrm{ha}^{-1}$ year $^{-1}$ on areas where the GAEC standard has been applied.

On the basis of this rough assumption, Figure 10 shows the set-aside area in the various years from 2004 to 2009 and the area where erosion did not likely exceed $3 \mathrm{Mg} \mathrm{ha}^{-1} \mathrm{yr}^{-1}$. Note the significant decrease in the areas at risk of erosion after the introduction of a no-tillage, obtained by extending the results collected in the case studies).

In conclusion, from the results of case studies it can be said for certain that the new form of set aside introduced by cross compliance, which forbids the yearly tillage of soil, has a very positive effect in reducing erosion, almost to its complete annulment.

Table 2. Soil use of the Centonara basin throughout the years (Ventura et al., 2004).

\begin{tabular}{|c|c|c|c|c|}
\hline Years & Autumn-winter crops \% & Spring crops \% & Natural vegetation cover $\%$ & Set aside \% \\
\hline 1994/95 & 53.8 & 26.5 & 19.7 & 0.0 \\
\hline 1995/96 & 38.8 & 36.4 & 23.9 & 0.9 \\
\hline 1996/97 & 31.6 & 36.7 & 30.0 & 1.7 \\
\hline 1998/99 & 33.6 & 8.7 & 33.2 & 24.5 \\
\hline $1999 / 2000$ & 33.0 & 27.3 & 32.7 & 7.0 \\
\hline
\end{tabular}

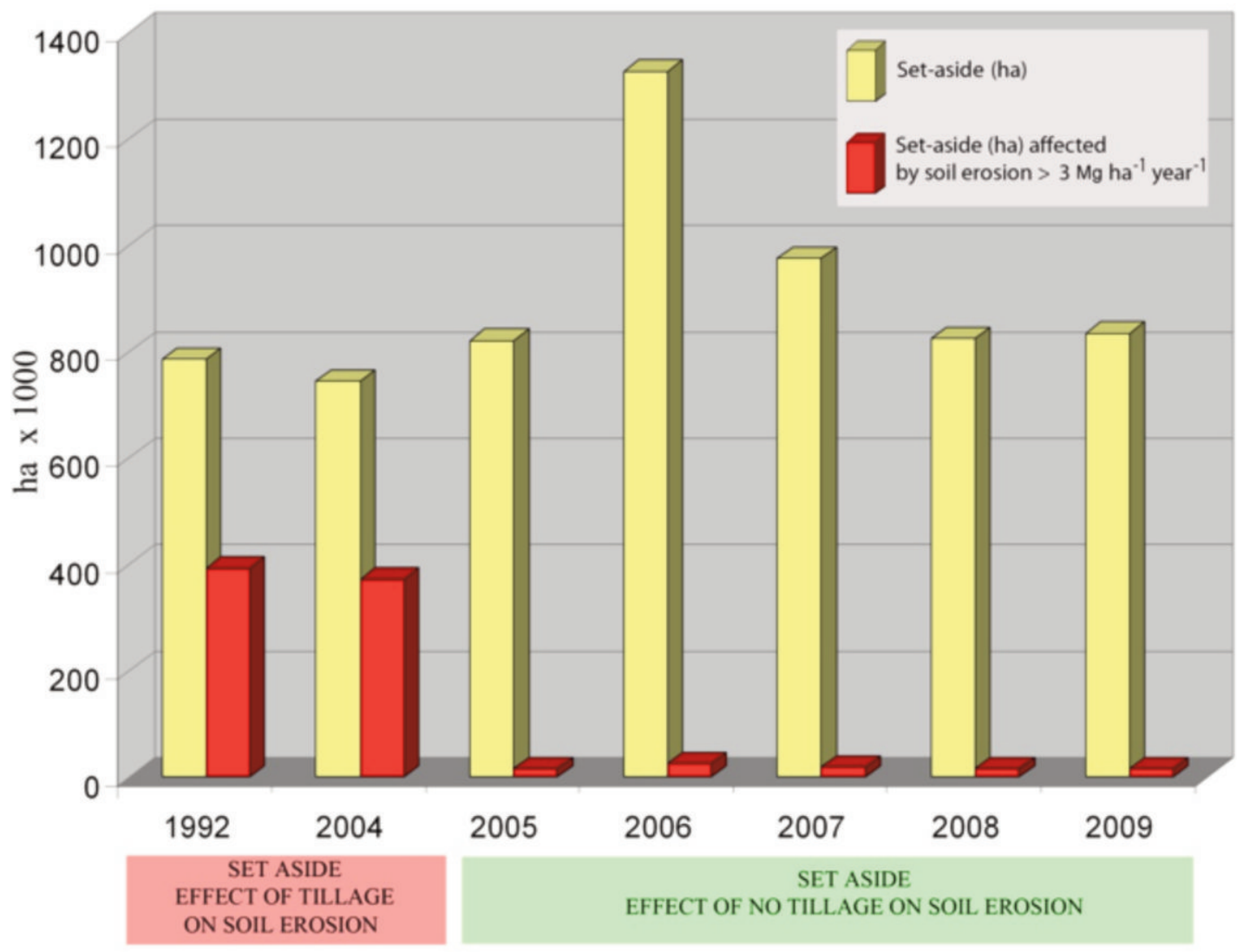

Figure 10. Set-aside area (ha) in the various years from 2004 to 2009 (source: MIPAAF for 1992 and AGRIT for the period 2004-2009) and the area where erosion did not likely exceed $3 \mathrm{Mg}$ $h^{-1} \mathrm{yr}^{-1}$. Note the significant decrease in the areas at risk of erosion after the introduction of a no-tillage, obtained by extending the results collected in the case studies. ). 


\section{References}

Bazzoffi P., 1993a. Fagna-type Hydrological unit for runoff measurement and sampling on experimental plots. Soil Technol. 6:251-259

Bazzoffi P., 1993b. The enhanced Fagna-type hydrological unit for measurement and sampling of runoff waters. pp 195-204 in Proc. Int. Workshop on Soil Erosion in Semi-Arid Mediterranean Areas. ESSC-CSEI, Taormina, Italy.

Bazzoffi P., Pellegrini S., Chisci G., Papini R., Scagnozzi A., 1997. Erosione e deflussi a scala parcellare e di bacino in suoli argillosi a diversa utilizzazione nella val d'Era. Agricoltura Ricerca 170:5-20.

Desmet P.J.J., Govers G., 1996. A GIS procedure for automatically calculating the USLE LS factor on topographically complex landscape units. J. Soil Water Conserv. 51:427-433.

Postiglione L., Ruggiero C., Carone F., Fagnano M., Mori M., 1997. Interventi finalizzati alla salvaguardia e all'utilizzazione del suolo nella collina interna della Campania. Agricoltura Ricerca 170:5162.

Raglione M., De Simone C., Rinaldini L., Francia U., 1997. L'erosione del suolo in aree collinari. Influenza di differenti tipi di coticoe confronto tra modelli di pascolamento e seminativi. Riv. Agron. 31:(Suppl.1)341-345.
Renard K.G., Foster G.R., Weesies G.A., McCool D.K., Yoder D.C., 1997. Predicting Soil Erosion by Water: A guide to conservation planning with the Revised Universal Soil Loss Equation (RUSLE). USDA, Agricultural Handbook No. 703, Government Printing Office, Washington, DC, USA.

Rivoira G., Balestra L., Roggero P.P., Santilocchi R., 1997. Impatto ambientale dei sistemi colturali nella fascia costiera adriatica: primi risultati sull'erosione e sulla qualità del deflusso superficiale e sottosuperficiale. Agricoltura Ricerca 170:33-50.

Soil Survey Staff, 1975. Soil taxonomy: a basic system of soil classification for making and interpreting soil surveys. USDA Soil Conservation Services, Agriculture Handbook No. 436, Government Printing Office, Washington, DC, USA.

Ventura F., Rossi Pisa P., Vicari A., 2004. Effect of land use on soil erosion in a small watershed of Emilia Romagna region. Ital. J. Agron. 8:29-36.

Wischmeier W.H., Smith D.D., 1978. Predicting rainfall erosion losses A guide for conservation planning. USDA, Agriculture Handbook No. 537, Government Printing Office, Washington, DC, USA.

Zanchi, C. 1990. Influenza delle cotiche erbose sul ruscellamento superficiale e sull'erosione in differenti condizioni pedoclimatiche. Agricoltura Ricerca 107:109. 